\title{
Review of Development of Hand Fan in the East and West Cultural Backgrounds
}

\author{
Longshanshan Huang ${ }^{1, a, \dagger, *}$ Yufei Liu ${ }^{2, b, \dagger, *}$ Jiayu Wang ${ }^{3, c, \dagger, *}$ \\ ${ }^{1}$ Bright Stella Studio. Changsha, Hunan 410000, China \\ ${ }^{2}$ Qingdao No.9 High School, Qingdao, Shandong 266011, China. \\ ${ }^{3}$ Macau University of Science and Technology, Macau 999078, China

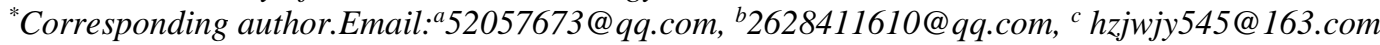

These authors contributed equally.

\begin{abstract}
The main research purpose is to explore the culture of hand fans in the East and the West. We hope that this article will enable readers to better understand the history of hand fans in different cultural backgrounds and the usage of hand fans in different eras. This article mainly adopts the research method of literature review. We reviewed some journals from China National Knowledge Infrastructure. In addition, We found some materials fromThe Fan Circle International and The Fan Museum in Greenwich and made an analysis and summary. In the eastern part, the article mainly introduces the development history of hand fans from the Jin Dynasty to the Qing Dynasty in China. It compares the functions and usage of hand fans in different social classes in detail. Then we had research on the gender expression of hand fans for men and women in different dynasties in China. This part reviews the changes in the gender expression of hand fans in stages. The article also introduces the development history of western hand fans from the 17th to 19th centuries and focuses on research during the Rococo period. The article explores the three functions of hand fans during the Rococo period: Status symbol, cultural communication, and fashion symbol. In addition, we also studied the gender expression of hand fans in different eras in the west and made a comparative analysis. By analyzing the development history of hand fans in the world and the different positioning of people of different genders using hand fans, we can clearly find something about changing the social status of men and women.
\end{abstract}

Keywords: Hand fan, Culture background, Function, Gender express

\section{INTRODUCTION}

In modern times, there are many films about characters and history in European and American films, and the costumes and props used in these films restore the scenes of that era. For example, Jane Austen's works, such as Pride and Prejudice and became Jane Austen's. These films all show the style of that era of clothing. In films that express the style of the historical era, props will appear with clothing, in which folding fans occupy a certain position. In the film <Marie Antoinette >, the Rococo style has been greatly disseminated. Many people also know and understand the Rococo style and the French court at that time and how Rococo's costumes were presented in that era. In this film, there are many scenes of folding fans, French nobles often holding folding fans, this folding fan is usually a Loco-style display. At the same time, in China, the hand fan culture has made great progress through the accumulation of Wei, Jin, and Ming Dynasties. At that time, eastern culture prevails, is introduced to the West, reflected in hand fans, and Chinese elements often appear in the Rococo style of fans. "The Chinese taste was in vogue. From the beginning of the 17th and 18th century, European fans often show influences of the Chinese taste, particularly on brise fans [1]." From the east at the turn of the 17th and 18th centuries, the Chinese taste was famous in Europe. It was exporting and importing fans. There are often influences of the Chinese style in the fan of European culture. With its unique cultural flavor and form, Chinese hand fans set off a frenzy in the West. This kind of cultural collision and fusion is undoubtedly exciting. Since then, Chinese hand fans have gone out of China and gradually entered the world. 
During this period, fans played an important role in spreading between East and West cultures. More and more Oriental culture through the fan spread to all West levels, affecting western art. In the 18th century, there is the first golden age of the fan in Europe. The fan as an essential fashion accessory in the society of Europe had gradually evolute particular the rich and fashionable classes. Because of the trade and development of the folding fan, this age ushered in the first golden period of folding fan in Europe in the 18th century. After that, the development of fans slowly declined.

Our study aims to sort out the development process of hand fans in the context of eastern and western culture. To achieve this goal, the main body of this paper will respectively elaborate on three aspects: cultural background, using and function, and gender expression in eastern and western. These three aspects make an analysis of the development process of the hand fans from multiple angles.

Different cultural backgrounds give birth to different ways of function. This study comes from the East and the West at the same time so that readers can have a more comprehensive understanding of the function of the hand fans. Based on function, this paper further analyzes the gender characteristics of hand fan function. The purpose of men using hand fans is different from that of women, so hand fans can also reflect the personality characteristics of men and women. These gender characteristics represent the common characteristics of men and women in society at that time. We can understand the status of men and women at that time according to these characteristics. To sum up, the value of this study is to make readers understand the hand fan culture and think about the status of men and women in today's society.

The second section presents the hand fans' culture in the East. The third section illustrates the culture of hand fans in the Rococo Era. The last section talks about the conclusion of the study.

\section{HAND FANS IN THE EAST}

The first part is the eastern part. We will sort it out from three aspects: the cultural background, using and function, and gender expression. The cultural background mainly introduces the history of the emergence and development of hand fans in China. The function will be sorted out from the direction of the upper society and many people. Finally, gender expression will explain the personality characteristics of men and women through some specific characters and examples.

\subsection{The birth and development of hand fans}

Fans caused two wild tides in the upper class of Chinese history. One was from the Wei and Jin Dynasties to the Northern and Southern Dynasties, and the other was in the Ming and Qing Dynasties. Most fans before Ming Dynasty couldn't call hand fans. They were ritual fans. At that time, the ritual fan was an instrument belonging to the upper class. As a ceremonial instrument, the fan had a high value for its heavy decoration, material, and shape [2]. The earliest ritual fan appeared in the Warring States period. In the Han Dynasty, it became a necessity for princes and nobles to go outside. The development of ritual Fan reached its peak in the Wei and Jin Dynasties, but after that, ritual fan culture gradually declined. In the following time, Chinese fan culture once went silent. At this time, the fan is facing a severe situation: the traditional mode cannot satisfy the needs of society, and the new way had not been developed. The foundation of the former fan culture's birth and development is ritual art. But with the end of the Wei and Jin Dynasties, ritual art also basically ended. Art returned to the creation of personal spirit. The ritual fan also declined [2]. This situation lasted until the Ming Dynasty. With the introduction of Japanese hand fans in the Ming Dynasty, Chinese fan culture had a new vitality. In Ming Dynasty, folding fans were widely imitated in court and folk [3]. At this time, the fan, also successfully changed from "ritual fan" to "hand fan", became popular and began to be popular in the court and folk at the same time. It can be seen that the development of hand fans is a process from symbolic meaning to practical application.

\subsection{Functions of hand fans in the history of China}

In China, hand fans have many uses, and with the development of society, their uses are constantly changing. Hand fans developed on a large scale in the Ming and Qing Dynasties and were popular in the upper class and common people at the same time. Therefore, the use of hand fans can be divided into two categories: upper-class society and folk.

For the people in the upper class, the symbolic meaning of the hand fan is more than the actual use. For them, the hand fan is more of a representation of status and a tool of emotional sustenance. For literati, the act of holding a hand fan in their hands symbolizes their status as literati. At the same time, they can design their own fans. Most literati would choose to draw plants representing the noble character, such as bamboo. Some literati can also write words on the fan. The content is a most famous aphorism or their favorite poems. They embody their noble character and lofty ambition in this way. Most of the hand fans used in the court have decorative functions and a symbol of noble status.

The folks are just the opposite. Among the common people, the hand fan is a practical tool and used as a symbol. As a tool, the main function of hand fans is to make their daily life more convenient and comfortable. Therefore, hand fans are often used to drive away 
mosquitoes and enjoy the cool. But it doesn't mean that they don't have a symbolic function among the people. On the contrary, in the Ming Dynasty, the citizen class was greatly interested in imitating the literati [3]. They imitated the literati and made folding fans for themselves. For a while, hand fans appeared in all walks of life. Unlike the upper class, the users here, regardless of their identity and gender, only use hand fans as tools for picture entertainment. Therefore, there is a situation of sharing elegance and vulgarity [3].

The ritual fans in Wei and Jin Dynasties were different. It completely gave up the use in life and completely served the literati, princes, and nobles. For example, in the Wei and Jin Dynasties, scholars like to use the form of a fan as a symbol of a material state to set off their identity as opinion leaders [4]. For example, when Emperor Wu of the Han Dynasty traveled, his subordinates would use specially made large fans on both sides of his car. The only function of this fan is to show his status as an emperor.

\subsection{The change of hand fan's gender express in Chinese history}

The fan culture is also inseparable from other cultures in China. China is a country that pays attention to etiquette and manners very much. For women, there is a very important decorative object called a hairpin. Fanshaped hairpins are one of the types of hairpins. In addition, when women hold fans, they can express their gentle and virtuous side, so fans are also props for ancient women to express their emotions and maintain their image. In the Tang Dynasty, hand fans in women's hands can reflect their luxury. Women in the Song Dynasty used fans to express simplicity and nature, and most women in the Song Dynasty used pocket-round fans. In the Ming Dynasty, China's fan culture began a new wave of development. At this time, women held fans to reflect their elegance and quietness. The Qing Dynasty was a period in Chinese history when China's development began to lag behind other countries. At that time, it was the decline of feudal society, and the oppression of women was obvious. Women became the lowest group in society. Therefore, the fans used by women in the Qing Dynasty generally represented frailty and sentimentality [2]. From the Tang Dynasty to the Qing Dynasty, the description of women's use of fans gradually changed from positive to negative, coinciding with the development and decline of the feudal system in Chinese history.

In many poems in China, fans are the literati's sustenance of their ideals. For example, the round fan means that others cannot discover one's talents, and the feather fan means that the ideal of life cannot be realized due to limited conditions. In the Three Kingdoms period of China, a famous person named Zhuge Liang, and the feather fan in his hand was his symbol. And this person was very smart. He often advised his master Liu Bei and always looks confident. His image is well-known now, so the feather fan has naturally become a symbol of wisdom and strategy. During the Ming and Qing dynasties, it was popular among Chinese literati to write poems and draw pictures on fans. Holding a fan can also allow men to show their demeanor in front of women [5]. The exquisite fan craftsmanship combined with the painting and calligraphy of the literati brought the fan culture to a new height. There are more than 150 poets whose theme is to praise fans in Chinese history, and they have composed thousands of poems. In China's four masterpieces, "A Dream of Red Mansions", fans were used as a medium to describe the characters' personalities [6]. There were many famous figures in the Ming Dynasty, such as Tang Bohu and Shen Zhou. These people also like to write poems or paint on fans. It can be seen that painting on a fan was a fashion in that era. Moreover, the fan also occupies a very important position in the minds of Chinese literati.

\section{THE EXPRESSION OF HAND FAN CULTURE IN THE WEST}

The fan has an important place in western history. Its development and function showed the characteristics of different periods of Western culture. At the same time, its development also shows the gender of history in a different period in the West. This section will present the hand fan culture in the West from the main historical, function, and gender express perspectives.

\subsection{The history of fan in the West}

The fan has a history of thousands of years. The basic function was used for cooling the body. In some early civilizations, the fan of value became artistic. The original development of folding fans was in China and Japan, and eastern cultures were largely exporting fans to the West. During the 17th,18th, and 19th, fans were a vital fashion accessory in Europe, and it was a luxurious article. The subjects of the fan describe different scenes, various cultures, and styles. The design of the fan continued in the middle of the 19th, the use of the fan descended in the society. Especially in contemporary times, the fans are usually used as a collectible and decoration in a whole garment $[7,8]$.

In the 17th century, England established trading companies to exploit and develop trade in the East. There is evidence with the infatuation of the east from Marco Polo's journey to the Renaissance at the court of Elizabeth of England [7]. By the end of Elizabeth's reign, fans as fashion accessories had a very significant status for the rich in the courts of Europe. The subjects on fans were famous paintings from mythology, the bible, and Roman history. 
In the 18th century, there was the first golden age of the fan in Europe. During this period, fans to being an essential fashion accessory for virtually all classes gradually [8]. And it was generally manufactured and traded in different countries. At the same time, the style of the fan went from Baroque to Rococo style. The materials of fans were hand-made lace and pastoral and romantic taste that decorated ivory or pearl, which was a great luxury article. In addition, there are a large number of exporting from the east in this period. The Chinese taste was in vogue [1]. In French, there are a large of very pretty fans, always painted on silk. We can see an example of a film in 2006, Marie Antoinette, in which the whole movie described the magnificent picture, in which the hand fan and the court dress always as a group be dressed on a female in public. Moreover, it used feathers, lace, jewelry, and painting to decorate hand fans. Then, the hand fan expressed feminine and soft feelings. During this time, the rococo style had a far-reaching influence on fans, and the decorations became lighter and more graceful [9].

In the 19th century, fans were in a period of recession. It became rustic and dainty. The 17 th and 18 th centuries that was in a period of decline of fans. With fashion, the style was simplicity and rusticity basically [10]. Between 1870 and 1900, fans began to be made and finished off part of garments. By the end of the 19th, the status of fans from an art item to an artware of mass production.

In modern times, for various reasons, the use of fans is becoming less and less. It functions as a collection for museums and an accessory for fashion. To be specific, the use of fans socially declined dramatically, and these are now very collectible in their own value [11].

\subsection{The usage of hand fans in the West}

The functions of fans in different periods are mainly reflected in the following aspects. Firstly, in the ancient West, fans were a social display of status. For example, luxurious design is a key decoration for hand fan in the court, French palace of women always carry a gorgeous hand fan with court dress to be social. Secondly, Fans make the culture of different countries communicate and spread. There is a house that is orient and eighteenthcentury rococo design. A sister received their clients in a Chinese-style room adorned with Coromandel lacquer, Song dynasty silks, and Louis XV furniture. This example illustrates the mutual influence of Chinese and Western cultures [9]. Thirdly, Fans as a fashion item, and clothing together with matching. In the past, the hand fan of court dress was decorated in various fashion styles, emphasizing feminine style and soft pastel color. For example, they always used peach, pink, and blue to decorate [9]. Nowadays, Designers often use fans of different period styles to express and match their garments. For instance, the best known evening dress was influenced by the East of eighteenth-century-inspired [9].

\subsection{Gender expression of hand fans in Rococo style}

In Europe, the people who can appreciate and use the Rococo style are the upper reaches. Most of them are. Rococo style is a combination of lithe and magnificence, delicacy, and complexity. It deliberately creates asymmetric visual effects and outlines women's beauty in contradictions and conflicts. The complicated and gorgeous patterns on the folding fan add a sense of mystery to women. The fan style of rococo was greatly developed in this period because of the high praise of the fan by Queen Mary of France. With a Rococo-style hand fan, women can show their charm at the same time. It also attracts the eyes of equally good men. The materials of flowers, flounces, ribbons, and lace, and the colour of soft pastel tones in citron, peach, pink, azure, and pistachio emphasized the opulent feminine style [9]. We can see that a traditional feminist dominates important status, the female beauty is to please male in this area [12].

However, in modern times, fans are used as a fashion item to show a woman's own style. For example, the fashion designer uses fans of a certain period as an element to match garments, which express the design concept. Now, women choose fans simply because they can express themselves as a style.

\section{CONCLUSION}

In conclusion, this article hopes to give you a better understanding of the history of hand fans under different cultural backgrounds and how to use it. We can further analyze the different meanings expressed by people of different genders when using the hand fan through the understanding of usage and function. This article introduces fan culture from two aspects: East and West. For the eastern fan culture, we mainly studied the development of Chinese fan culture. Fans have existed since the Wei and Jin Dynasties in China. China's fan culture has a profound cultural background. In the upper class of ancient China, hand fans were mostly used to show identity. In the folk, hand fans can also be used as a daily tool, such as enjoying the cool air. For the use of hand fans in the folk, people also like to imitate the literati painting on the fans. Although both men and women in ancient China used fans, over time, the gender expressions embodied by fans have also been different. In this part, we also did a retrospective study on gender expression. In addition, we also briefly explained the status of modern Chinese fans.

Regarding Western fan culture, we first briefly introduce the history of the development of hand fans over the centuries. Next, give examples of the artistic style of Western hand fans in the 17th and 19th centuries and the usage of hand fans as decorative objects. For the fan culture in the 18th century, the European Rococo period was selected to describe it. This part describes the 
further development of the hand fan in the Rococo period and also describes the important position it in the court at this time. It also shows that the Rococo period was the golden period for the development of Western fan culture. The main functions of hand fans in the Rococo era are as follows: status symbol, cultural dissemination, and fashion representation. In terms of gender expression, in the west, in the past, women used hand fans to show the beauty and charm to men's aesthetics. In contemporary times, hand fans are only used as props for women to express their own style and no longer exist to cater to men.

It can be seen from the article that regardless of whether it is in the West or the East, fans have evolved from their own to each other. Many hand fans in the west also have many eastern patterns. The hand fan born from the combination of Eastern and Western cultures is a sublimation of fan culture. Obviously, with the development of time, the fan has gradually evolved into a stage prop. Few people in modern society regard hand fans as a symbol to express themselves. In the modern role of hand fans, most of them appear as stage props in performances.

By analyzing the development history of hand fans in the world, and the different positioning of people of different genders using hand fans, we can better find that the social status of men and women is changing. In the past, women used fans to show their beauty and to attract the attention of men. The fan culture has developed to this day. With the awakening of gender consciousness, women no longer dress just to please men. Through this article, readers' thinking about the issue of men and women is even more aroused.

\section{REFERENCES}

[1] A. G. Bennett, Unfolding Beauty- The Art of the Fan, published by Thames and Hudson, 1988

[2] Q.Y.Diao.The Concepts and Aesthetics of Artifacts: Decline and Return of Chinese Fans from the Designing Perspective. Shanghai Art and Crafts(3), 2020,pp. 56-58.

[3] Q. Sun. J. Liao(Eds.), The change of vulgarity and elegance -- on the popularity of folding fans and nicknames in Ming Dynasty. Shanghai Drama Institute, 2020, pp. 2.

[4] F. Ji, E.P. Zhang. On the social communication function of fans in Chinese culture. Southeast Communication, 2021, pp. 1.

[5] S.Q. Lu.The Fan Culture in China. China Education Innovation Herald(20), 2013,pp. 90-91.

[6] B. Zhang. The Literati Comlex in Chinese Fan Culture. China Academic Journal Electronic Publishing House(9), 2011, pp. 169-170.
[7] N. Armstrong, Fans, published by Souvenir Press. 1984.

[8] S. Mayor, Fans, published by Charles Letts, 1990.

[9] Breward, J. B. Eicher, J. S. Major, P. Tortora, Encyclopedia of clothing and fashion, E-book, Charles Scribners\& Sons, 2004

[10] N. Armstrong, The book of Fans, published by Mayflower books, 1978.

[11] N. Armstrong, a Collector's History of Fans. London: Studio Vista,1974.

[12] G. Ambrose, The visual dictionary of fashion design, E-book, Charles Scribners\& Sons, 2007. 